\title{
Konstruksi Realitas Kehidupan dalam Video Klip Lagu Tong Hua
}

\author{
Tivanny Claranita, Riris Loisa \\ tivannyclaranita@yahoo.co.id
}

Fakultas Ilmu Komunikasi Universitas Tarumanagara

\begin{abstract}
Song Video Clip is a form of Audio Visual Aids (AVA) media that contains pitcure and lyrics. Usually, a song contain messages that relate to real life. Through this mandarin song, "Tong Hua "meaning fairy tale, a message about reality is constructed. Fairy tale can be understood as a story that will not happen in real life. When we hear the word "Fairy Tale", we tend to imagine a life full of happiness. Then, in reality of life, it does not always bring happiness. This is why, the purpose of this research is to describe the reality of human life that is constructed through this song from a video clip. In this research, several theories are used, such as construction of reality and semiotic. Qualitative descriptive and semiotic by Ronald Barthes method is used to decode the denotation, connotation and myth of the song. From this research, it was then concluded that happiness is not a form of reality objective and to construct happiness into reality that needs a long process of internalization. This process include non-verbal action as well as myth and traditional culture value to prove that human can live happily if they believe and work hard.
\end{abstract}

Keywords: Audio Visual Aids Media, Construction Reality of Human Life, Semiotic

\begin{abstract}
Abstrak
Video klip lagu merupakan salah satu bentuk media Audio Visual Aids (AVA) yang terdiri dari gambar dan lirik. Pada umumnya, lagu berisi pesan-pesan yang berkaitan dengan realitas. Melalui lagu Mandarin "Tong Hua" (Dongeng), sebuah realitas dikonstruksi. Dongeng dapat dipahami sebagai cerita yang tidak benar-benar terjadi dan tidak masuk akal. Jika mendengar kata "dongeng" tak jarang manusia akan membayangkan kehidupan yang bahagia di dalam sebuah kerajaan. Lantas, dalam realitas kehidupan sering terjadi hal-hal yang tidak membahagiakan. Penelitian ini bertujuan untuk mengetahui lebih dalam terkait makna realitas kehidupan manusia dan bagaimana mengkonstruksinya. Dalam penelitian ini menggunakan beberapa teori yang relevan, seperti konstruksi realitas kehidupan, dan semiotika. Dengan menggunakan acuan pendekatan kualitatif deskriptif dan metode semiotika Roland Barthes untuk mengkaji makna denotasi, konotasi, dan mitos. Melalui penelitian ini, melahirkan nilai objektivitas dan subjektivitas, serta ditemukan makna yang berkaitan dengan realitas dan dapat disimpulkan bahwa kebahagiaan bukan merupakan sebuah realitas, melainkan subjektivitas dan untuk membangun kebahagiaan menjadi realitas membutuhkan proses internalisasi yang sangat panjang. Proses tersebut mencakup tindakantindakan non verbal serta mitos dan budaya nilai tradisional untuk membuktikan bahwa manusia dapat hidup bahagia jika percaya dan bekerja keras.
\end{abstract}

Kata kunci: Media Audio Visual Aids, Konstruksi Realitas Kehidupan, Semiotika

\section{Pendahuluan}

Setiap proses komunikasi membutuhkan media untuk menyampaikan pesan. Dari berbagai ragam media yang ada, salah satunya yaitu melalui lagu. Lagu merupakan hasil dari karya manusia yang dituangkan ke dalam video klip dan lirik. Pada umumnya, lagu untuk menyampaikan pesan-pesan yang berkaitan dengan 
kehidupan manusia. Tak jarang lagu-lagu diciptakan untuk mengkritisi sebuah realias kehidupan. Melihat lagu sebagai media dalam menyampaikan pesan, seorang penyanyi kelahiran Malaysia bernama Guang Liang membuat dan menyanyikan sebuah lagu Mandarin. Lagu yang berdurasi 7 menit 37 detik ini debut pada tanggal 21 bulan Januari tahun 2005 di Taiwan dan berjudul Tong Hua.

Tong Hua jika diterjemahkan ke dalam Bahasa Indonesia artinya Dongeng. Nurgiyantoro (2018), memaparkan bahwa dongeng merupakan salah satu cerita rakyat (folktale) yang cukup beragam cakupannya. Istilah dongeng dapat dipahami sebagai cerita yang tidak benar-benar terjadi dan dalam banyak hal yang sering tidak masuk akal. Jika mendengar kata dongeng, tak jarang manusia akan membayangkan sebuah kisah cinta yang romantis terjadi antara seorang pangeran dengan putri, seperti cerita Cinderella, Putri Salju, Putri Tidur dimana tokoh utama wanita mengalami kesulitan. Kemudian, seorang pangeran atau seorang peri datang untuk membantunya dengan cara-cara yang tidak masuk akal sehingga pada akhir cerita pangeran dan putri hidup bahagia selamanya. Dalam kenyataan hidup, tentunya tidak ada hal yang abadi selamanya. Semua orang belum tentu dapat hidup bahagia seperti pada cerita dongeng. Setiap manusia pasti dapat mengalami kelahiran, sakit, tua dan kematian. Hanya saja proses yang dialami oleh manusia, berbeda-beda. Tanggal kelahiran, sakit, tua dan kematian juga berbeda-beda pada setiap orang. Walaupun demikian, tapi menurut Guang Liang, setiap orang tetap seharusnya memiliki sebuah dongeng di dalam hati. Jika ingin memiliki ending yang bahagia, maka harus berusaha dan pantang menyerah untuk meraihnya (Sumber: www.baike.baidu.com).

Dalam lagu Tong Hua, pesan yang ingin disampaikan oleh Guang Liang memiliki kaitan erat dengan realitas kehidupan. Melalui lagu tersebut, sebuah realitas dikonstruksi. Lantas realitas tentang kehidupan yang seperti apa dan bagaimana mengkonstruksinya menjadi pertanyaan bagi penulis. Oleh karena ingin menemukan jawabannya, maka menarik bagi penulis untuk meneliti lebih dalam mengenai makna dari lagu tersebut. Penulis akan mengkaji lagu tersebut dengan menggunakan metode semiotika untuk megetahui dan mendeskripsikan makna realitas tentang kehidupan yang dikonstruksi oleh video klip lagu.

Penelitian ini menggunakan beberapa tinjauan pustaka untuk menjadi acuan dalam menjalankan penelitian. Berikut beberapa teori yang digunakan:

Media Massa

Menurut Bittner (dalam Romli, 2016), komunikasi massa adalah pesan yang dikomunikasikan melalui media massa pada sejumlah besar orang. Dari definisi tersebut, dapat diketahui bahwa komunikasi massa itu harus menggunakan media massa. Tanpa media, komunikasi massa tidak dapat dilakukan. Media massa adalah sebuah perantara dan sebagai tempat untuk menyampaikan sebuah pesan kepada sejumlah khalayak yang berjumlah besar. Menurut bentuknya, media terbagi atas menjadi beberapa bentuk, yaitu:

a. Media cetak, bentuk dari media komunikasi yang dilaksanakan melalui proses percetakan. Misalnya: surat kabar, buku, brosur, dan lain sebagainya

b. Media visual atau media pandang, bentuk dari media komunikasi yang disampaikan melalui panca indera dan dapat dilihat. Objeknya cenderung diam ataupun juga bergerak. Biasanya media visual dapat memenuhi pesan non verbal komunikator. Misalnya: gambar, foto, video klip, dan lain sebagainya 
c. Media audio, bentuk dari media komunikasi yang disampaikan melalui suara dan diterima melalui indra pendengaran. Misalnya: radio, rekaman musik, dan lain sebagainya

d. Media Audio Visual Aids (AVA), bentuk dari komunikasi yang disampaikan melalui suara dan gambar sehingga dapat memenuhi pesan verbal dan non verbal secara bersamaan. Misalnya: televisi, laptop, dan lain sebagainya

Dalam kehidupan sehari-hari, masyarakat membangun sebuah realitas melalui tindakan dan interaksi individu. Menurut Wibowo (2011), konstruktivisme adalah suatu filsafat pengetahuan yang menekankan bahwa pengetahuan kita adalah konstruksi (bentukan) kita sendiri, oleh karena pengetahuan bukanlah tiruan dari suatu kenyataan (realitas).

Berger dan Luckman (Bungin, 2008), menjelaskan realitas dengan memisahkan pemahaman "kenyataan" dan "pengetahuan". Realitas diartikan sebagai kualitas yang terdapat di dalam realitas-realitas yang diakui sebagai keberadaan yang tidak tergantung pada kehendak sendiri. Sedangkan pengetahuan didefinisikan sebagai kepastian bahwa realitas-realitas itu nyata dan memiliki karakter yang spesifik. Substansi teori dan pendekatan konstruksi realitas dari Berger dan Luckman adalah pada proses simultan yang terjadi secara alamiah melalui bahasa dalam kehidupan sehari-hari. Institusi masyarakat tercipta dan dipertahankan atau diubah melalui tindakan dan interaksi manusia. Meskipun masyarakat dan institusi sosial terlihat nyata secara objektif, namun pada kenyataan semuanya dibangun dalam definisi subjektif melalui proses interaksi.

Menurut Moller (2011), video klip adalah sebuah film pendek atau video yang mendampingin alunan musik, umumnya sebuah lagu. Dalam Kamus Besar Bahasa Indonesia (KBBI), lagu adalah ragam suara yang berirama dalam bercakap, bernyanyi, membaca, dan sebagainya. Lagu juga memiliki banyak macam fungsi. Selain berfungsi sebagai media dalam menyampaikan pesan, yaitu untuk menghibur. Lagu biasanya didengarkan oleh khalayak dalam berbagai macam situasi, lagu bisa menghibur khalayak dari kesedihan juga dapat membangkitkan semangat seseorang (Sumber: kbbi.co.web).

Video klip lagu menghasilkan sensasi audio visual kepada khalayak untuk menceritakan sebuah pesan lagu. Dalam video klip terdapat lirik lagu. Dalam Bahasa Yunani, lirik lagu adalah sebuah syair yang dinyanyikan dalam sebuah permainan. Seperti permainan vokal gaya bahasa dan penyimpangan makna kata merupakan permainan bahasa dalam menciptakan lirik lagu. Maka diketahui bahwa lirik lagu telah menggunakan gaya bahasa dan penyimpangan makna kata, sehingga terkadang makna yang ingin disampaikan oleh pencipta lirik tidak tersampaikan dengan baik. Oleh karena itu, dalam dunia ilmu komunikasi terdapat teori analisa semiotika, analisa wacana, analisa isi, maupun analisa framing untuk mengkaji lebih dalam mengenai makna yang sebenarnya dari lirik tersebut.

Pada umumnya, lagu digunakan untuk menyampaikan masalah-masalah yang terjadi dalam kehidupan, terkadang mengkritisi sebuah kehidupan, terkadang mendukung sebuah isu yang sedang hangat terjadi, terkadang juga merepresentasikan sebuah perilaku kejahatan sosial. Lagu menjadi media yang penting bagi seorang pencipta lagu untuk menyampaikan pemikirannya dan membaangun sebuah realitas, terutama dalam membahas kehidupan sosial.

Dalam teori Barthes, Barthes mengembangkan semiotika menjadi 2 tahap signifikasi. Tahap pertama, merupakan hubungan antara penanda dan pertanda. Tahap satu ini mengandung makna denotasi. Denotasi adalah tingkat pertandaan 
yang menjelaskan hubungan penanda dan pertanda pada realitas, menghasilkan makna eksplisit, langsung, dan pasti. Sedangkan konotasi adalah tahap ke dua yang berada pada tingkatan pertandaan yang menjelaskan hubungan penanda dan pertanda yang di dalamnya beroperasi makna yang tidak eksplisif, tidak langsung, dan tidak pasti.

Teori Barthes ini merupakan penerus dari pemikiran Saussure. Jika Saussure menekankan pada tanda dalam sebuah konteks, Barthes menekankan interaksi antara teks dengan pengalaman personal dan kultural pengguna, interaksi antara konvensi dalam teks dengan konvensi yang dialami dan diharapkan oleh penggunanya. Barthes juga melihat aspek lain dari penandaan, yaitu "mitos". Mitos adalah bagaimana budaya menjelaskan dan bekerja dalam beberapa gejala realitas sosial.

\section{Metode Penelitian}

Dalam penelitian ini, menggunakan pendekatan kualitatif untuk menguraikan dan mendeskripsikan makna dibalik dari tanda, lambang, maupun simbol. Selain itu, juga menggunakan metode penelitian analisis semiotika, karena untuk mencari tahu makna realitas dari lagu Tong Hua.

Dalam penelitian ini, yang menjadi subjek penelitian adalah sesepuh/tokoh budaya Tionghoa untuk mengetahui bagaimana unsur budaya Tionghoa dalam lagu tersebut. Serta, ahli Sosiologi untuk menanyakan hal-hal terkait realitas kehidupan. Sedangkan, yang akan menjadi objek penelitian adalah beberapa potongan gambar dari video klip dan lirik lagu Tong Hua yang berdurasi 7 menit 37 detik.

Menurut cara memperolehnya, data dapat terbagi atas:

1. Data Primer, melalui media Youtube. Penulis mengambil video klip yang resmi diunggah oleh perusahaan musik yang menaungi penyanyi lagu Tong Hua pada saat itu dan membagikannya ke dalam beberapa potongan gambar sebagai unit analisis. Serta melakukan metode wawancara untuk keabsahan data. Penulis akan melakukan wawancara mendalam terhadap beberapa narasumber

2. Data Sekunder, mengambil data dari sumber yang telah ada. Dalam penelitian ini, penulis mengambil bahan-bahan teori mengenai penelitian penulis melalui studi kepustakaan, buku-buku, jurnal online, maupun terbitan penelitian serupa. Untuk mempermudah penulis dalam mengolah dan analisis data, penulis membaginya ke dalam beberapa langkah berikut, yaitu:

1. Membagi video klip lagu Tong Hua ke dalam beberapa potongan screenshoot beserta lirik lagu. Tentunya beberapa potongan video klip tersebut, diduga memiliki makna yang lebih mendalam terkait pesan realitas kehidupan.

2. Reduksi data, memilih kembali bagian-bagian yang wajib dianalisis.

3. Melakukan analisis berdasarkan semiotika Roland Barthes untuk memperoleh makna denotasi, konotasi, dan mitos.

4. Wawancara mendalam sebagai data pendukung kepada subjek penelitian untuk bertanya mengenai hasil analisis dan mengaitkannya kepada keahlian/bidang yang dimiliki oleh masing-masing narasumber. Proses ini termasuk ke dalam proses verifikasi dan triangulasi data.

5. Menarik kesimpulan secara deskriptif. 


\section{Hasil Temuan dan Diskusi}

Penulis memperoleh beberapa temuan melalui beberapa adegan video klip pada lagu Tong Hua. Berikut temuannya:

Gambar 1. Hilang Kepercayaan terhadap Kebahagiaan

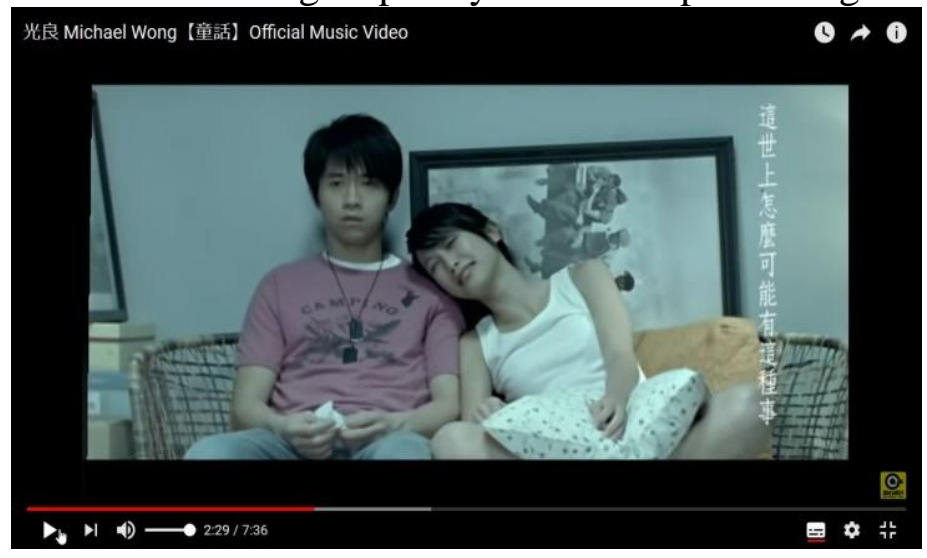

Sumber: youtube.com (2018)

Secara denotasi, lagu Tong Hua menampilkan kisah sepasang kekasih yang ingin hidup bahagia seperti di dalam dongeng. Namun, karena adanya realitasrealitas kehidupan sehingga tokoh utama wanita hilang kepercayaannya terhadap kehidupan yang bahagia. Akan tetapi, tokoh utama laki-laki tidak putus asa. Melalui lirik lagu "Kamu harus percaya, percaya kita bisa menjadi seperti di dalam dongeng, kebahagiaan dan kesenangan adalah akhir cerita" yang terus berulang pada bagian reff lagu diharapkan dapat menanamkan kembali rasa kepercayaan tersebut.

Gambar 2. Penggunaan Warna Hitam

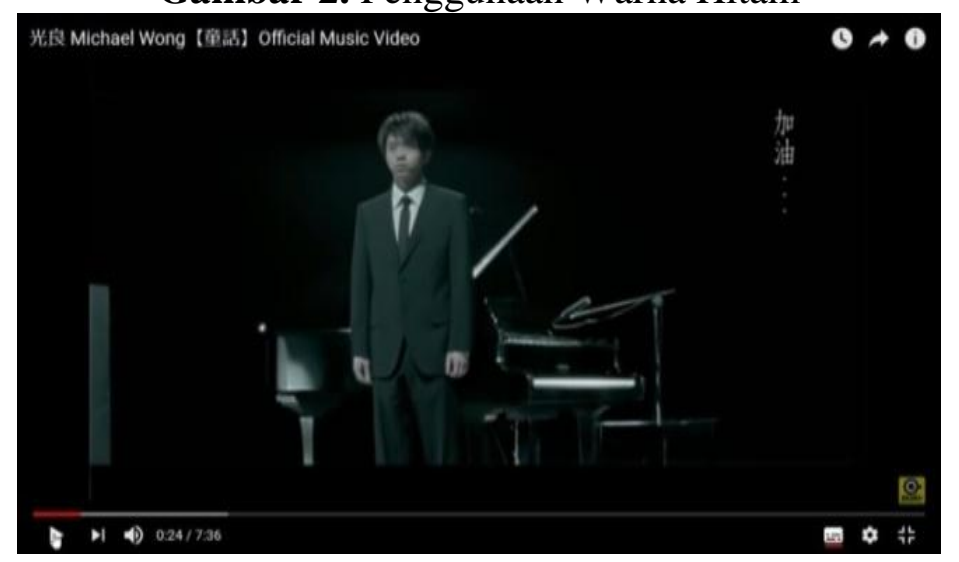

Sumber: youtube.com (2018)

Secara konotasi, dalam video klip lagu Tong Hua, menggunakan warna hitam untuk menggambarkan suasana yang gelap, dingin, dan suram, serta banyak menampilkan simbol-simbol non verbal, seperti kontak mata, gesture tubuh, ekspresi wajah. Melalui adegan pertama, mendapatkan makna bahwa ternyata dibalik kesuksesan seseorang terdapat kisah dibaliknya. Dalam lagu tersebut, kisah cinta merupakan kisah dibaliknya. 


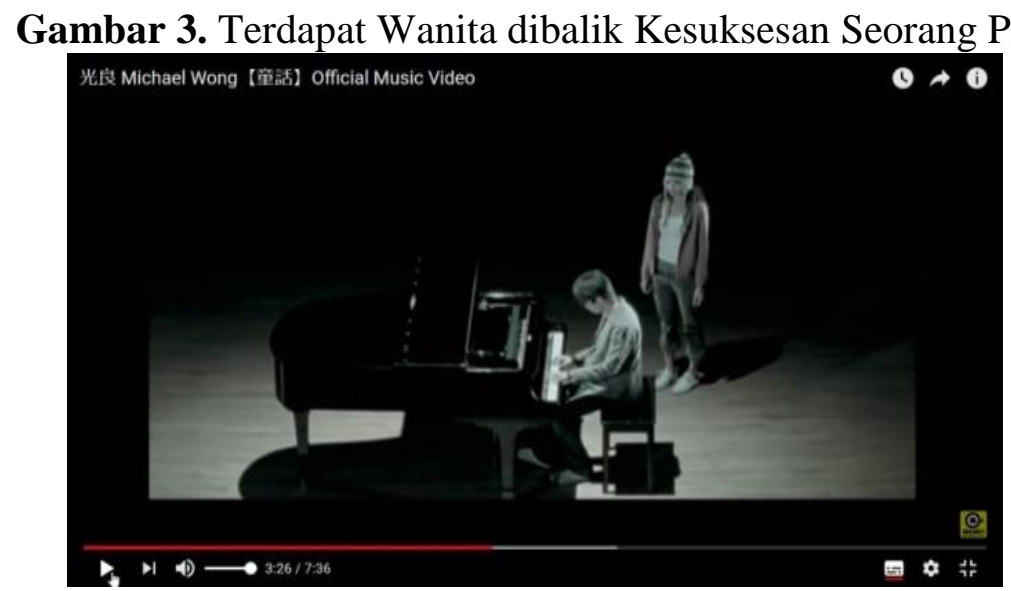

Sumber: youtube.com (2018)

Dibalik kesuksesan seorang pria, ternyata terdapat wanita hebat dibelakangnya. Walaupun kisah cinta mereka tidak dapat seperti cerita-cerita bahagia di dalam dongeng, karena terdapat realitas yang menghambat proses kebahagiaan tersebut. Dalam realitas kehidupan, manusia dapat mengalami kesakitan yang membuat seseorang tidak bahagia dan kematian yang membuat seseorang harus terpisah dengan orang yang dicintai. Hal ini terdapat kontradiksi (bertentangan) dengan lirik lagu yang menyampaikan makna subjektivitas. Kebahagiaan dalam dongeng dapat terjadi jika manusia percaya. Melalui lirik lagu, sebuah realitas yang bersifat subjektif ingin dibangun. Namun, prosesnya sangat panjang, karena terdapat pertentangan antara nilai objektivitas dengan subjektivitas.

Dalam video klip, tokoh wanita tidak percaya pada dongeng. Sedangkan, tokoh laki-laki percaya. Itu disebabkan oleh nilai subjektivitas yang berbeda dan untuk membangun realitas yang bersifat subjektif ini, membutuhkan sebuah proses yang panjang. Proses mempersuasi ini membutuhkan tindakan-tindakan manusia. Dalam video klip, melalui cinta tulus dari tokoh utama laki-laki, seperti menelepon kekasihnya disaat sebelum konser, memberi bahunya disaat kekasihnya sedih sebagai tanda menghibur, memberi perhatian dengan penuh ketulusan, menjaga kekasihnya disaat sakit. Tindakan-tindakan ini adalah proses membangun sebuah nilai subjektif menjadi sebuah realitas yang objektif. Pada akhirnya tokoh wanita belum tentu menerima realitas yang dibangun secara subjektif tersebut.

Dibalik makna-makna yang terselubung dalam sebuah tanda, terdapat budaya yang bekerja dibaliknya untuk memantapkan penyampaian makna yang tidak terlihat. Secara mitos, budaya-budaya tradisional terutama budaya yang berasal dari budaya Tionghoa cukup mempengaruhi tindakan-tindakan yang dilakukan dalam video klip lagu Tong Hua. 
Gambar 4. Budaya Ojigi

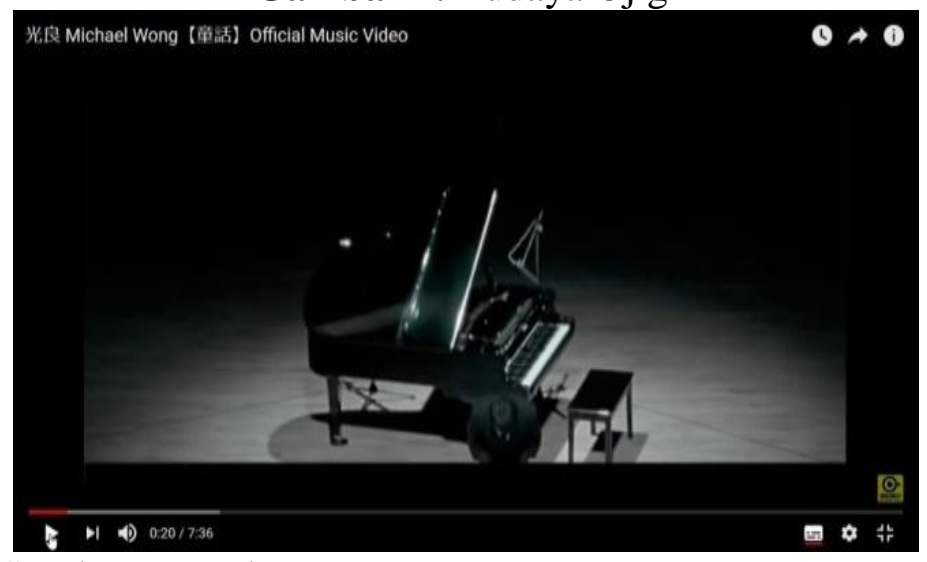

Sumber: youtube.com

Melalui video klip dan lirik lagu, penulis menangkap beberapa mitos yang bekerja dibalik lagu tersebut. Pada adegan pertama, budaya ojigi adalah budaya berterima kasih yang telah diadaptasi oleh budaya Jepang. Budaya ojigi berasal dari ajaran Tionghoa dan sudah tidak dilakukan lagi oleh orang Tionghoa, kecuali dalam acara-acara yang sangat formal. Menurut salah satu narasumber ahli budaya Tionghoa, budaya ojigi ternyata tidak hanya untuk berterima kasih, namun untuk melakukan penghormatan kepada orang yang lebih tua.

Selain itu, juga ada Xin Ren (kepercayaan) yang dianut oleh budaya Tionghoa. Dengan memiliki kepercayaan, manusia percaya bahwa feng shui bergantian berputar. Tidak selamanya akan berada di dalam keadaan yang buruk, namun suatu hari feng shui yang baik juga akan berputar kemari. Maka itu, masyarakat harus memiliki budaya etos kerja yang tinggi dan memiliki cita-cita setinggi langit untuk menyambut kedatangan feng shui yang baik. Konon jika seseorang memiliki feng shui yang baik akan membawakan nasibnya menjadi baik, makmur, sehat, bahagia, serta berpengaruh terhadap anak cucunya untuk ikut memiliki nasib yang baik. Untuk memiliki feng shui yang baik, maka sama saja manusia harus bekerja keras untuk meraih sebuah kesuksesan. Dibalik kesuksesan seorang pria, biasanya ada wanita yang hebat dibelakangnya. Wanita yang akan membantu pria untuk membereskan kehidupan rumah tangga disaat prianya harus bekerja keras di luar. Walaupun era kehidupan modern ini, telah banyak wanita yang tidak lagi mengurus rumah tangga melainkan keluar mencari pekerjaan. Mitos-mitos tersebut merupakan budaya tradisional yang sampai saat ini masih dipercaya oleh masyarakat Tionghoa.

Jika dikaitkan dengan teori konstruksi realitas kehidupan, Berger dan Luckman (Bungin, 2008), menjelaskan realitas dengan memisahkan pemahaman "kenyataan" dan "pengetahuan". Realitas diartikan sebagai kualitas yang terdapat di dalam realitas-realitas yang diakui sebagai keberadaan yang tidak tergantung pada kehendak sendiri. Sedangkan pengetahuan didefinisikan sebagai kepastian bahwa realitas-realitas itu nyata dan memiliki karakter yang spesifik. Berdasarkan hasil analisis penulis mengenai makna denotasi, konotasi, dan mitos, maka lagu Tong Hua sebagai media komunikasi realitas kehidupan ingin menyampaikan sebuah pesan mengenai kehidupan indah di dalam dongeng. Dongeng bukanlah sebuah realitas, melainkan sebuah nilai subjektivitas. Dalam lagu tersebut, ingin membangun sebuah realitas yang bersifat subjektif, yaitu kebahagiaan. Proses ini berupa proses internalisasi, yaitu proses penyerapan kembali dunia objektif ke alam subjektif sedemikian rupa sehingga subjektif individu dipengaruhi oleh struktur dunia sosial. 
Dalam menghadapi realitas ini, pengetahuan dan kenyataan menjadi kunci utama untuk memahaminya. Realitas yang dianut oleh manusia memang berbeda-beda dan terkadang manusia juga membangun realitas sendiri melalui pandangan pribadi dan itu membutuhkan sebuah proses yang sangat panjang.

\section{Simpulan}

Secara denotasi, lagu Tong Hua mengkonstruksi sebuah realitas mengenai kebahagiaan seperti di dalam dongeng, serta ingin membangun sebuah kepercayaan terhadapnya. Secara konotasi, lagu Tong Hua melahirkan dua hal yang bertentangan, yaitu nilai objektivitas dan nilai subjektivitas. Pada satu sisi, manusia harus mengalami sakit dan kematian, sedangkan pada satu sisinya lagi manusia ingin memiliki kehidupan yang bahagia. Selain itu, lagu Tong Hua ingin menampilkan kisah dibalik kesuksesan seorang musisi. Orang yang sukses belum tentu akan bahagia. Kebahagiaan adalah sebuah nilai subjektivitas, melainkan bukan realitas. Setiap manusia berhadapan dengan realitas sakit dan kematian sehingga hilang kepercayaan terhadap kebahagiaan. Melalui lagu ini, terdapat keinginan untuk membangun kembali realitas tersebut menjadi objektif. Proses konstruksi kembali ini, membutuhkan proses yang panjang. Melalui tindakan-tindakan non verbal dan juga mitos yang mempengaruhi tindakan manusia dalam membangun kembali realitas, membuat seseorang merasakan kebahagiaan supaya orang tersebut percaya terhadap realitas kebahagiaan.

Melalui lagu ini, terdapat penanaman nilai-nilai tradisional, adat istiadat, budaya, kepercayaan yang masih dianut oleh masyarakat Tionghoa hingga saat ini, namun sebagian telah ditinggalkan oleh masyarakat perkotaan. Maka itu, realitas tentang kehidupan yang bahagia serta nilai-nilai tradisional ingin dikonstruksi kembali oleh lagu Tong Hua melalui proses internalisasi (penanaman nilai-nilai subjektivitas) yang mencakup tindakan-tindakan nyata yang dipengaruhi oleh gerakan non verbal, seperti sorot mata ketulusan, emosi, ekspresi, warna, serta mitos dan penanaman nilai-nilai tradisional untuk membuktikan bahwa manusia dapat hidup bahagia asalkan percaya dan bekerja keras. Namun, pada akhirnya kembali lagi kepada masing-masing individu untuk memandang kehidupannya seperti apa.

\section{Ucapan Terima Kasih}

Penulis mengucapkan banyak terima kasih kepada pihak yang telah memberi konstribusi dalam penelitian ini, terutama kepada ibu Dr. Riris loisa, M.Si selaku dosen pembimbing serta bantuan dari narasumber yang telah meluangkan waktu berharga untuk melakukan wawancara.

\section{Daftar Pustaka}

Bungin, B. (2008). Konstruksi Sosial Media Massa: Kekuatan Pengaruh Media Massa, Iklan Televisi, dan Keputusan Konsumen serta Kritik terhadap Peter L. Berger \& Thomas Luckman. Jakarta: Kencana.

Fiske, J. (2012). Pengantar Ilmu Komunikasi (Edisi 3 buku ke-1 Penerjemah Hapsari Dwiningtyas). Jakarta: Rajawali Pers. 
Fitrah, M., \& Lutfiyah. (2017). Metodologi Penelitian: Penelitian Kualitatif, Tindakan Kelas dan Studi Kasus. Sukabumi: CV Jejak.

Lam, N. M., \& Graham, J. L. (2007). China Now. Jakarta: PT. Elex Media Komputindo.

Lin, L. S. (2009). Tu Po She Jiao Kun Jing. China: Shan Dong Dian Zi Yin Xiang Chu Ban She.

Moleong, L. J. (2010). Metodologi Penelitian Kualitatif. Bandung: Remaja Rosda Karya.

Moller, D. (2011, Maret 24). Redifining Music Video. Retrieved September 7, 2018, from Major Written Assessment: http://danmoller.com.au/wpcontent/uploads/2011/03/Dan_Moller_-_Redefining_Music_Video.pdf

Nurgiyantoro, B. (2018). Sastra Anak: Pengantar Pemahaman Dunia Anak. Yogyakarta: Universitas Gajah Mada Press.

Rabiger, M., \& Cherrier, M. H. (2013). Directing: Film Techniques and Aesthetics (Fifth edition). New York and London: Focal Press.

Romli, K. (2016). Komunikasi Massa. Jakarta: PT. Grasindo.

Rustan, A. S., \& Hakki, N. (2017). Pengantar Ilmu Komunikasi. Yogyakarta: Deepublish.

Sobur, A. (2009a). Analisis Teks Media: Suatu Pengantar untuk Analisis Wacana, Analisis Semiotik dan Analisis Framing. Bandung: PT. Rosdakarya.

Sobur, A. (2009b). Semiotika Komunikasi. Bandung: PT. Rosdakarya.

Sugiyono. (2012). Memahami Penelitian Kualitatif. Bandung: ALFABETA.

Suryani, \& Hendryadi. (2015). Metode Riset Kuantitatif: Teori dan Aplikasi pada Penelitian Bidang Manajemen dan Ekonomi Islam. Jakarta: Prenadamedia Group.

Timotius, K. H. (2017). Pengantar Metodologi Penelitian: Pendekatan Manajemen Pengetahuan untuk Perkembangan Pengetahuan. Yogyakarta: ANDI (Anggota IKAPI).

West, R., \& Tunner, L. H. (2008). Pengantar Teori Komunikasi: Analisis dan Aplikasi (buku 1 edisi ke-3 Terjemahan Maria Natalia Damayanti Maer). Jakarta: Salemba Humanika.

Wibowo, I. S. (2011). Semiotika Komunikasi: Aplikasi Praktis bagi Penelitian dan Skripsi Komunikasi. Jakarta: Mitra Wacana Media. 